\title{
Correspondence
}

To the Editors

\section{Clinical and laboratory profile of children with COVID-19 admitted at a tertiary care hospital in Karnataka, Southern India}

\author{
Sri Lanka Journal of Child Health, 2022: 51(1): 165-166
}

DOI: http://dx.doi.org/10.4038/sljch.v51i1.10033

(Key words: Laboratory, Children, COVID-19)

Dear Editors,

We like to share some ideas on the publication "Clinical and laboratory profile of children with COVID-19 admitted at a tertiary care hospital in Karnataka, Southern India"1. Sahana KS, et al concluded that "Presence of undernutrition and elevated C-reactive protein were associated with severe illness". In this study, some laboratory parameters were studied and there might be important confounding effects. As Sahana KS, et al ${ }^{1}$ noted, some children have nutritional problems which might affect some laboratory parameters such as ferritin and haemoglobin. Additionally, a nutrition risk screening (NRS) score should be applied. In a previous report, NRS score was a good predictor for clinical outcome in cases with sepsis and it might be applicable to cases with COVID- $19^{2}$. Finally, the treatment given to different children might be different and it can result in different clinical outcomes. Those cases with atypical presentation may have received additional medications and it can affect both clinical outcome and clinical parameters. For example, steroids can affect the platelet count and might help to improve the clinical outcome.

\section{References}

1. Sahana KS, Prabhu AS, Saldanha PRM, Sudhir SMK, Gurmitkal B. Clinical and laboratory profile of children with COVID19 admitted at a tertiary care hospital in Karnataka, Southern India. Sri Lanka Journal of Child Health 2021; 50(3): 5039.

https://doi.org/10.4038/sljch.v50i3.9733

2. Gao Q, Cheng Y, Li Z, Tang Q, Qiu R, Cai $\mathrm{S}$, Xu X, Peng J, Xie H. Association between nutritional risk screening score and prognosis of patients with sepsis. Infection and Drug Resistance 2021; 14: 3817-25.

https://doi.org/10.2147/IDR.S321385

PMid: 34557005 PMCid: PMC8455294

\author{
*Pathum Sookaromdee ${ }^{1}$, Viroj Wiwanitkit ${ }^{2}$ \\ ${ }^{1}$ Private Academic Consultant, Bangkok Thailand \\ ${ }^{2}$ Honorary Professor, Dr. DY Patil University, Pune, \\ India \\ *Correspondence: pathumsook@gmail.com \\ orcid.org/ 0000-0002-8859-5322
}

\section{$\underline{\text { Response by authors of article }}$}

Dear Editors

We appreciate the interest of the reader in our article. Nutritional Risk Screening (NRS) 2002 score is most widely studied in adults though in paediatrics appropriate Nutrition Screening Tools (NSTs) are still being developed ${ }^{1}$. So, their applicability needs to be further evaluated in the paediatric population. We agree that the presence of undernutrition may influence various laboratory parameters. On literature review, it was noted that the serum ferritin concentration was elevated in all types of infection as acute phase protein, even in severely malnourished children but it was still lower than normal $^{2}$. The World Health Organisation (WHO) also stated that in the presence of widespread inflammation, interpretation of serum ferritin level is difficult and concurrent measurement of other acute phase reactants can aid in the interpretation ${ }^{3}$. All the laboratory parameters were done before initiation of treatment, so it is unlikely that treatment has affected the laboratory parameters. The type of treatment was warranted by different clinical presentations and it was according to the available guidelines at that time.

\section{References}

1. Lee YJ. Nutritional screening tools among hospitalized children: From past to present. Pediatric Gastroenterology, Hepatology and Nutrition 2018; 21:79-85. https://doi.org/10.5223/pghn.2018.21.2.79 PMid: 29713604 PMCid: PMC5915694

2. Atiar Rahman M, Mannan MA, Rahman $\mathrm{MH}$. Influence of infection on iron profile in severely malnourished children. Indian Journal of Pediatrics 2009; 76(9): 907-11. 
https://doi.org/10.1007/s12098-009-0098$\mathrm{x}$

PMid: 19381490

3. WHO. Serum ferritin concentrations for the assessment of iron status and iron deficiency in populations. Vitamin and Mineral Nutrition Information System. Geneva, World Health Organization 2011 (WHO/NMH/NHD/MNM/11.2).

Available from: http://www.who.int/vmnis/indicators/seru m_ferritin.pdf (Accessed on 9/10/2021).

*Sahana K S S, $^{1,2}$ Anitha S Prabhu ${ }^{1,2}$, Prakash R M Saldanha $^{1,2}$, Shyam M K Sudhir ${ }^{1.2}$, Balakrishna Gurmitkal $^{2}$

${ }^{1}$ Yenepoya Medical College ${ }^{2}$ Yenepoya University, Mangalore, Karnataka, India

*Correspondence: dr_sahana2003@yahoo.co.in

iD https://orcid.org/ 0000-0002-7834-0289 